\title{
Influence of the Blood Meal Source on the Biology of Meccus picturatus Usinger 1939 (Hemiptera: Reduviidae: Triatominae) under Laboratory Conditions
}

\author{
José Alejandro Martínez-Ibarra ${ }^{+}$,Mónica Novelo López, \\ María del Rosario Hernández Robles, Yunuen Grant Guillén
}

\author{
Área de Entomología Médica, Laboratorio de Salud Pública, Centro Universitario del Sur, Universidad de Guadalajara, \\ A. P. 20, 49000 Ciudad Guzmán, Jalisco, México
}

\begin{abstract}
Aspects related to hatching, time-lapse between presenting the blood meal and beginning of feeding, feeding time, postfeed defecation delay, life time, mortality and fecundity for each stage of Meccus picturatus, life-cycle were evaluated and compared in two cohorts of M. picturatus fed on hens or rabbits. The hatching rate observed for each of the two studied groups of eggs was $78.1 \%(n=2298)$ on the group fed on hens and $82.1 \%(n=2704)$ on that fed on rabbits, and the average time of hatching was 20 days. Mean time-lapse for beginning feeding was under 3 min in nymphal stages and postfeed defecation delay was under $10 \mathrm{~min}$ in all stages, in both cohorts. Mean feeding time was significantly $(P<0.05)$ shorter in triatomines fed on hens than on rabbits. A similar number of nymphs of each cohort, 69 fed on hens (34.5\%) and 68 fed on rabbits (34\%), completed the cycle. No significantly $(P>0.05)$ differences were recorded among the average times from NI to adult in the cohort fed on hens (196.8 \pm 15.8 days) and the average time in the cohort fed on rabbits (189.5 \pm 22.9$)$. The average span in days for each stage fed on hens was not significantly different to the average span for each stage fed on rabbits. The number of blood meals at each nymphal stage varied from 1 to 6 in both cohorts. The mortality rates were higher on fifth nymphal stage, in both cohorts. No significant $(P>0.05)$ differences were recorded on mortality rates on most nymphal stages of both cohorts. The average number of eggs laid per female from the cohort fed on hens in a 9-month period was 791.1, whereas the average number of eggs in the cohort fed on rabbits was 928.3.
\end{abstract}

Key words: Meccus picturatus - biology - blood source - laboratory conditions

The genera Triatoma and Meccus include several species considered very important for the transmission of Trypanosoma cruzi to human populations in Mexico, mainly according to their capacity to colonize domestic environments (Velasco-Castrejón 1991, Guzmán-Bracho 2001, Martínez-Ibarra et al. 2001a). Meccus picturatus (Usinger), is one of the most important vectors of Chagas disease in this country since its frequent contact with men as a blood meal source and high infection rates with T. cruzi (De la Torre et al. 1990, Velasco-Castrejón et al. 1994, Magallón-Gastélum et al. 1998, 2001, MartínezIbarra et al. 2001a). This species usually occurs in houses, chicken coops in villages and sylvatic focus of western Mexico (Lent \& Wygodzinsky 1979, Zárate \& Zárate 1985, Magallón-Gastélum et al. 1998, 2001, Martínez-Ibarra et al. 2001a). In spite of the important role of M. picturatus in the transmission of $T$. cruzi to human populations in an extensive area of Mexico, the biology and behavior of this species is documented in only one work (Gomes \& Silva 2001), however, the influence of the blood meal source in the life cycle and some related biological parameters is not documented.

$\overline{{ }^{+} \text {Corresponding author. Fax: }}$ +52-341-41.24044. E-mail: aibarra@cusur.udg.mx

Received 1 July 2002

Accepted 6 January 2003
Taking into account the associations of this species in natural and artificial environments and previous information on its host preferences, the objective of this study was to know the life cycle and reproductive development of $M$. picturatus in Mexico and to determine the influence of the blood meal source on it.

\section{MATERIALS AND METHODS}

A laboratory colony established in 2000 from specimens captured in Compostela, Nayarit was used. The colony was maintained at $27 \pm 1^{\circ} \mathrm{C}$ and $75 \%$ relative humidity (rh) and fed weekly on immobilized Leghorn hens or New Zealand rabbits.

Eggs were grouped by date of oviposition to initiate two cohorts of 200 eggs each. After eclosion, the two groups of first-instar nymphs were separated individually into plastic containers $(5.5 \mathrm{~cm}$ diameter $\mathrm{x} 10.5 \mathrm{~cm}$ height), with an upcenter support of absorbent cardboard. Three days after eclosion, each cohort of nymphs were individually fed on Leghorn hens or New Zealand rabbits during a $1 \mathrm{~h}$ period until the first blood meal, after that they were fed weekly. Nymphs were observed from the beginning of feeding through $1 \mathrm{~h}$ postfeeding for recording feeding and defecation behaviors. The bugs were maintained in a dark incubator at $27 \pm 1^{\circ} \mathrm{C}$ and $75 \% \mathrm{rh}$, and were checked daily for ecdysis or death.

From the insects that completed development to the adult stage, 10 adult couples of each cohort were placed in individual containers $(5.5 \mathrm{~cm}$ diameter $x 10.5 \mathrm{~cm}$ height $)$ and maintained as previously described to determine oviposition patterns. 
The variables that showed a normal distribution were compared by Student t-test or analysis of variance (ANOVA). In the case of ANOVA tests, post hoc comparisons were made using the Scheffé test. The Wilcoxon nonparametric test was used for variables with a nonnormal distribution. The chi-square test was used for comparison of frequencies. The differences were considered to be significant when $\mathrm{P}<0.05$.

\section{RESULTS}

Egg eclosion rate was $78.1 \%$ in the cohort fed on hens and $82.1 \%$ in the cohort fed on rabbits, with an average incubation period of 20 days (range 18-25 days) in both cohorts. Sixty nine nymphs ( 40 males and 29 females) completed development to the adult stage from the cohort fed on hens (Table I), taking an average of 2.7 blood meals per nymphal stage (range 1-6) (Table II). Sixty eight nymphs ( 36 males and 32 females) completed development to the adult stage from the cohort fed on rabbits (Table I), taking an average of 2.7 blood meals per nymphal stage (range 1-5) (Table II). The average egg-to-adult development time was 196.8 days (range 173-229) on the cohort fed on hens (Table I) and 189.5 days (range 169-221) in the cohort fed on rabbits. The average number of eggs laid per female from the cohort fed on hens in a 9-month period was 791.1 (range 737.1-847.8), whereas the average number of eggs in the cohort fed on rabbits was 928.3 (range 688.5-1120.5).

Mean time-lapse for beginning feeding was under 3 min for nymphal stages, in both cohorts and for adults of the cohort fed on rabbits (Table III) with no significant (P $>0.05)$ differences among cohorts. Mean feeding times were significantly $(\mathrm{P}<0.05)$ shorter on each stage for the

TABLE I

Egg to adult development cycle of Meccus picturatus fed every seven days on hens or rabbits

\begin{tabular}{|c|c|c|c|c|c|c|c|c|}
\hline \multirow[b]{3}{*}{ Stage } & \multicolumn{8}{|c|}{ Duration in days } \\
\hline & \multicolumn{4}{|c|}{ Hens } & \multicolumn{4}{|c|}{ Rabbits } \\
\hline & (n) & Min. & Max. & Mean \pm SD & (n) & Min. & Max. & Mean \pm SD \\
\hline Egg-NI & 144 & 18 & 24 & $20.7 \pm 0.35$ & 150 & 18 & 25 & $21.03 \pm 0.44$ \\
\hline NI-NII & 133 & 18 & 33 & $20.8 \pm 3.62$ & 139 & 18 & 36 & $21.7 \pm 3.16$ \\
\hline NII-NIII & 114 & 14 & 44 & $23.6 \pm 6.84$ & 125 & 14 & 49 & $21.5 \pm 5.7$ \\
\hline NIII-NIV & 110 & 24 & 58 & $32.5 \pm 6.17$ & 103 & 27 & 78 & $33.2 \pm 7.43$ \\
\hline NIV-NV & 97 & 31 & 85 & $45.8 \pm 14.3$ & 91 & 21 & 77 & $43.1 \pm 10.8$ \\
\hline NV-AD & 69 & 39 & 82 & $58.6 \pm 10.3$ & 68 & 40 & 67 & $56.3 \pm 6.19$ \\
\hline Total & 69 & 173 & 229 & $196.8 \pm 15.8$ & 68 & 169 & 221 & $189.5 \pm 22.88$ \\
\hline
\end{tabular}

TABLE II

Number of blood meals and stage mortality for Meccus picturatus fed on hens and rabbits under laboratory conditions

\begin{tabular}{|c|c|c|c|c|c|c|}
\hline \multirow[b]{3}{*}{ Stage } & \multicolumn{3}{|c|}{ Hens } & \multicolumn{3}{|c|}{ Rabbits } \\
\hline & \multicolumn{3}{|c|}{ No. blood meals } & \multicolumn{3}{|c|}{ No. blood meals } \\
\hline & No. nymphs & Mean $\pm \mathrm{SD}$ & $\%$ mortality & No. nymphs & Mean \pm SD & $\%$ mortality \\
\hline $\mathrm{I}$ & 144 & $1.20 \pm 1.29$ & 7.7 & 150 & $1.06 \pm 0.24$ & 7.3 \\
\hline II & 133 & $1.56 \pm 2.13$ & 14.3 & 139 & $1.48 \pm 0.52$ & 10.1 \\
\hline III & 114 & $1.58 \pm 0.52$ & 3.5 & 125 & $1.59 \pm 0.60$ & 17.6 \\
\hline IV & 110 & $1.74 \pm 0.78$ & 11.8 & 103 & $1.5 \pm 0.65$ & 11.6 \\
\hline $\mathrm{V}$ & 97 & $2.20 \pm 0.89$ & 28.9 & 91 & $2.34 \pm 0.73$ & 25.3 \\
\hline Total & 69 & - & $(66.2)$ & 68 & - & (71.9) \\
\hline
\end{tabular}

TABLE III

Mean time-lapse for beginning feeding, mean feeding time and postfeed defecation delay in Meccus picturatus fed on hens and rabbits, under laboratory conditions

\begin{tabular}{|c|c|c|c|c|c|c|}
\hline \multirow[b]{2}{*}{ Stage } & \multicolumn{2}{|c|}{$\begin{array}{l}\text { Mean time (min) for } \\
\text { starting a blood meal }\end{array}$} & \multicolumn{2}{|c|}{$\begin{array}{l}\text { Mean feeding time (min) } \\
\text { Mean } \pm \text { SD }\end{array}$} & \multicolumn{2}{|c|}{$\begin{array}{c}\text { Defecation delay (min) } \\
\text { Mean } \pm \text { SD }\end{array}$} \\
\hline & Hens & Rabbits & Hens & Rabbits & Hens & Rabbits \\
\hline I & $1.1 \pm 0.2$ & $1.4 \pm 0.9$ & $2.8 \pm 3.95$ & $11.7 \pm 5.4$ & $2.6 \pm 3.78$ & $2.4 \pm 4.1$ \\
\hline II & $1.8 \pm 2.2$ & $1.6 \pm 2.5$ & $9.6 \pm 4.58$ & $21.8 \pm 7.1$ & $5.7 \pm 8.03$ & $3.1 \pm 1.5$ \\
\hline III & $1.2 \pm 1.8$ & $1.5 \pm 2.2$ & $7.8 \pm 3.27$ & $14 \pm 6.8$ & $2.3 \pm 3.6$ & $6.3 \pm 4.7$ \\
\hline IV & $1.7 \pm 2.3$ & $2.3 \pm 3.2$ & $7.8 \pm 5.13$ & $18 \pm 7.8$ & $4.6 \pm 8.28$ & $9.1 \pm 5.2$ \\
\hline V & $2.7 \pm 3.4$ & $1.7 \pm 2.3$ & $8.9 \pm 4.7$ & $22.7 \pm 7.5$ & $5.4 \pm 4.45$ & $7.9 \pm 4.7$ \\
\hline Female & $4.3 \pm 4.3$ & $1.2 \pm 2.5$ & $4.9 \pm 2.79$ & $14.8 \pm 6.1$ & $7.5 \pm 4.75$ & $4.9 \pm 3.5$ \\
\hline Male & $4.7 \pm 5.1$ & $1.5 \pm 3.4$ & $5.3 \pm 3.1$ & $15.7 \pm 7.4$ & $7.1 \pm 4.62$ & $5.1 \pm 4.1$ \\
\hline
\end{tabular}


cohort fed on hens than those for the cohort fed on rabbits (Table III). Postfeed defecation delay was under 10 min in all stages, for both cohorts (Table III) with no significant $(\mathrm{P}>0.05)$ differences among them.

A partial life table analysis, following the methods of Southwood (1978), indicates a net reproductive rate (Ro) of 114.7 times per generation under these conditions for the cohort fed on hens, with an instantaneous daily reproductive rate (r) of 0.0094 (Table IV). A net reproductive rate (Ro) of 148.53 times per generation under these conditions was indicated for the cohort fed on rabbits, with an instantaneous daily reproductive rate (r) of 0.0099 (Table IV).

\section{TABLE IV}

Partial stage specific life table for Meccus picturatus (Notation following Southwood 1978)

\begin{tabular}{lrrrrr}
\hline & \multicolumn{2}{c}{ Hens } & & \multicolumn{2}{c}{ Rabbits } \\
\cline { 2 - 3 } \cline { 5 - 6 } Stage & Lx & Dx & & Lx & Dx \\
\hline Egg & 200 & 56 & & 200 & 50 \\
I & 144 & 11 & & 150 & 11 \\
II & 133 & 19 & & 139 & 14 \\
III & 114 & 4 & & 125 & 22 \\
IV & 110 & 13 & & 103 & 12 \\
V & 97 & 28 & & 91 & 23 \\
Adult & 69 & 69 & & 68 & 68 \\
\hline
\end{tabular}

$$
\begin{aligned}
& \text { Ro }=\frac{\begin{array}{c}
\text { No of females produced by cohort } x \text { mean eggs } \\
\text { laid per female }
\end{array}}{\text { No of eggs beginning a cohort }} \\
& \text { Ro }(H)=114.7 \\
& \operatorname{Ro}(\mathrm{R})=148.5 \\
& r=\log (\text { Ro)/egg-to-egg generation time }=0.0094(H), 0.0099(\mathrm{R}) \\
& \mathrm{Lx}=\mathrm{nr} \text { entering stage } \mathrm{x} ; \mathrm{dx}=\mathrm{nr} \text { dying in stage } \mathrm{x}
\end{aligned}
$$

\section{DISCUSSION}

The development cycle of a triatomine varies according to the species, the environmental conditions and the availability of blood sources (Schofield 1985); many species are also influenced by the kind of these sources. According to some authors (Juarez 1970, Diotaiuti \& Dias 1987, Lima-Gomes et al. 1990, Braga et al. 1998, Guarneri et al. 2000a, b) the life cycle of at least 7 Triatominae species (4 Triatoma spp.) were shorter on cohorts reared on mammals (mice) than on those reared on birds (chicken, pigeons or hens). However, Cabello et al. (1987) reported a longer life cycle of Rhodnius neivai fed on rabbits than fed on hens. In the current study, the average development time of the cohorts of $M$. picturatus fed on hens (196.8 \pm 15.8 days) and fed on rabbits $(189.5 \pm 22.9$ days $)$ were not significantly $(\mathrm{P}>0.05)$ different. These results could be expected, based on previous accounts of the natural association of these species with chicken and hens as much as with rodents on the wild of the same geographic area of Mexico (De la Torre et al. 1990, MagallónGastélum et al. 1998, 2001, Martínez-Ibarra 2000, MartínezIbarra et al. 2001a).
The average development time of the cohorts of $M$. picturatus fed on hens $(196.8 \pm 15.8$ days $)$ and fed on rabbits ( $189.5 \pm 22.9$ days) were shorter than the average development time of some Mexican Triatominae species, such as 897.5 days for T. nitida feeding weekly on mice and maintained at $28 \pm 1^{\circ} \mathrm{C}$ and $80 \pm 5 \%$ rh (Galvão et al. 1995), than the development time of 272.3 days for $M$. picturatus feeding on hens to different frequencies on each nymphal stage and maintained at $25 \pm 0.5^{\circ} \mathrm{C}$ and $57 \pm$ $10 \%$ rh (Gomes \& Silva 2001), than the development time of 240 days (range 180-336 days) for M. dimidiatus feeding fortnightly on rabbits and maintained at $26.5 \pm 0.5^{\circ} \mathrm{C}$ and $50 \pm 5 \%$ rh (Zeledón et al. 1970a), and than the development time of 235.77 days for $M$. mazzottii feeding weekly on rabbits and maintained at $27 \pm 2^{\circ} \mathrm{C}$ and $70 \%$ rh (Malo et al. 1993). The average development time in our study was longer than for other Mexican Triatominae species. Novelo López and Martínez-Ibarra (2002) recorded an average development time of 185 days (range 148-226 days) for M. pallidipennis fed weekly on rabbits and maintained at $27 \pm 1^{\circ} \mathrm{C}$ and $75 \pm 5 \% \mathrm{rh}$. Gomes and Silva (2001) reported an average development time of 175.5 days for $M$. picturatus fed under different feeding frequencies on hens on each nymphal stage and maintained at $25 \pm 0.5^{\circ} \mathrm{C}$ and $57 \pm 10 \%$ rh. Martínez-Ibarra and Katthain-Duchateau (1999) recorded an average development time of 168 days (range of 131-199 days) for M. pallidipennis fed weekly on hens and maintained at $27 \pm 2^{\circ} \mathrm{C}$ and $60 \pm 5 \%$ rh. Martínez-Ibarra et al. (2001b) reported an average development time of 161.7 days (range of 88-325 days) for $M$. dimidiatus fed weekly on rabbits and maintained at $27 \pm$ $3^{\circ} \mathrm{C}$ and $65 \pm 5 \%$ rh. Zárate (1983) reported an average development time of 143.7 days for females and 205.3 for males of $T$. barberi fed every 4.2 days on rabbits and maintained at $27^{\circ} \mathrm{C}$ and $60 \pm 10 \% \mathrm{rh}$.

Egg hatching rates in Triatominae species also vary. They are generally above $80 \%$ (Zeledón et al. 1970b, Rabinovich 1972, Zárate 1983, Braga et al. 1998, Cabello \& Lizano 2001, Gomes \& Silva 2001), although percentages less than $75 \%$ have been recorded for most Mexican triatomines, such as M. mazzottii (58.7\%) (Malo et al. 1993), M. pallidipennis $(60 \%)$, (Martínez-Ibarra \& KatthainDuchateau 1999), M. picturatus (65.5\%) (Gomes \& Silva 2001), T. gerstaeckeri (65.9\%) (Galaviz-Silva et al. 1991) and M. dimidiatus (66.7\%) (Martínez-Ibarra et al. 2001b). Egg hatching rates in M. picturatus in this study $(78.1 \%$ on the cohort fed on hens and $82.1 \%$ in the cohort fed on rabbits) reflects the similarity between conditions in the natural habitats of $M$. picturatus and those present in laboratory conditions.

Mortality showed an irregular pattern. The lowest mortality rate was in the molt from third to fourth stage on the cohort fed on hens, and from first to second in the cohort fed on rabbits. Meanwhile the highest mortality was between the fifth to adult, in both cohorts, similar to M. dimidiatus (Zeledón et al. 1970a), T. infestans (Rabinovich 1972), T. barberi (Zárate 1983), M. pallidipennis (Martínez-Ibarra \& Katthain-Duchateau 1999) and T. rubida sonoriana (Paredes-González et al. 2003). In the youngest nymphs, mortality appeared to be due mainly to an incapacity to feed, since dead bugs were generally 
without significant intestinal content. In contrast, mortality in the older nymphs occurred mainly during their molting. No significant $(\mathrm{P}>0.05)$ differences were recorded on the accumulative mortality rates in both cohorts of this study $(H=66.13, R=71.92)$. These similarity on mortality rates among two cohorts of the same species fed on different blood meal sources was also observed on $T$. pseudomaculata and $T$. sordida fed on pigeons and mice (Guarneri et al. 2000a, b). Accumulative mortality rates in both cohorts of this study were significantly $(\mathrm{P}<0.05)$ higher than for other Mexican Triatominae species, such as T. barberi (Zárate 1983), M. mazzottii (Malo et al. 1993), M. pallidipennis (Martínez-Ibarra \& Katthain-Duchateau 1999), M. dimidiatus (Martínez-Ibarra et al. 2001b). On average, approximately $75 \%$ of I-IV stages, and $50 \%$ of V stage of both cohorts required one and a half meals in order to molt to the next stages.

Mean time-lapse for beginning feeding was under 3 min in most stages of both cohorts, with no significant $(\mathrm{P}>0.05)$ differences among them, except on adults of the cohort fed on hens. These shorter mean time for beginning feeding were shorter than those for M. dimidiatus, $T$. infestans (Zeledón et al. 1977), or even R. prolixus (Pippin 1970, Zeledón et al. 1977) considered some of the most important Chagas disease vectors in America (WHO 1991) and similar to T. barberi (Zárate et al. 1984) considered one of the most important Chagas disease vectors in Mexico (Salazar-Schettino et al. 1988, Velasco-Castrejón 1991, Velasco-Castrejón et al. 1994, Velasco-Castrejón \& Salazar-Schettino 1996, Guzmán-Bracho 2001).

Mean feeding time was significantly $(\mathrm{P}<0.05)$ longer on the cohort fed on rabbits than in the cohort fed on hens. This result was similar to that recorded by Guarneri et al. (2000b) and by Sant'Anna et al. (2001) in eight Triatominae species, where the rate of engorgement on pigeons tended to be greater than that obtained for mice. This fact may be related to intrinsic differences between these hosts (a bird and a mammal on each work) possibly associated with differences in the haemostatic mechanisms of birds and mammals (Lehane 1966). In our experiments using rabbits, interruptions during the meal were longer, which lead us to the idea that feeding on mammals is more difficult than on birds, requiring more contact time to obtain a similar quantity of blood, as recorded in previous studies (Guarneri et al. 2000b, Sant' Anna et al. 2001) using mice and pigeons as blood meal sources. Mean feeding times obtained on birds tended to be longer than on mammals, probably due to differences on host haemostasis. Although basic mechanisms of haemostasis are very conserved amongst vertebrates, the blood of birds and mammals has different haemostatic features. Birds have thrombocytes that play the same function as mammalian platelets; however, thrombocytes are less effective, since they do not respond with the same intensity to platelet aggregation inducers. Birds also appear to lack some coagulation factors, particularly in the intrinsic coagulation system (Lewis 1996).

Mean feeding time of the two cohorts were shorter than those reported for T. s. texana, T. gerstaeckeri (Pippin 1970), T. infestans (Zeledón et al. 1977), and T. nitida (Galvão et al. 1995). Mean feeding time of the cohort fed on rabbits was similar to $R$. prolixus (Pippin 1970, Zeledón et al. 1977), T. barberi (Zárate et al. 1984), M. mazzottii (Malo et al. 1993), and M. dimidiatus, (Martínez-Ibarra et al. 2001b), these four latter considered some of the most important vectors of transmission of $T$. cruzi to human populations in Mexico.

According to Zeledón et al. (1977), triatomines are in intimate contact with their victim at least in the first 5 to 10 min after feeding. In consequence, species that defecate on that period could be considered potentially effective transmitters of T. cruzi to humans, as T. infestans, $R$. prolixus (Pippin 1970, Zeledón et al. 1977) and both cohorts of $M$. picturatus in this study.

The typical development time and high reproductive rate may reflect how closely the experimental conditions were controlled to match the optimal conditions for this species. The average net reproduction rate (Ro) for the cohort of M. picturatus fed on hens was 114.7, and was of 148.5 for the cohort fed on rabbits; this latter result was similar to that for M. pallidipennis (145.4), a related Mexican Triatominae species, from a nearby geographical area (Martínez-Ibarra \& Katthain-Duchateau 1999). The average net reproduction rate (Ro) of each cohort were higher than those calculated for T. barberi reared under very similar controlled conditions $($ Ro = 89.1) (Zárate 1983), for T. maculata reared under similar controlled conditions $($ Ro $=80.5)($ Feliciangeli \& Rabinovich 1985) and that calculated for T. infestans reared under different controlled conditions $(\mathrm{Ro}=25)$ (Rabinovich 1972).

Most of the studied parameters showed no significant $(\mathrm{P}>0.05)$ differences among the cohort fed on hens and for fed on rabbits, reflecting the possible association of M. picturatus to mammals as much as to birds in wild ecotopes, which could facilitate their colonization of human dwellings in their distribution area. Results on the studied parameters added to the above facts, lead us to conclude, as suggested by previous field studies (Magallón-Gastélum et al. 1998, Martínez-Ibarra et al. 2001a), that M. picturatus could be considered an important potential transmitter of $T$. cruzi to human population in those areas of Mexico where it is currently present.

\section{ACKNOWLEDGEMENTS}

To Diana Monserrat Martínez-Grant for helping in the development of this study.

\section{REFERENCES}

Braga MV, Pinto ZT, Lima MM 1998. Life cycle and reproductive patterns of Triatoma rubrofasciata (De Geer, 1773) (Hemiptera: Reduviidae), under laboratory conditions. Mem Inst Oswaldo Cruz 93: 539-542.

Cabello DR, Lizano E 2001. Biology of Triatoma flavida Neiva 1911 (Hemiptera: Reduviidae) under laboratory conditions. Mem Inst Oswaldo Cruz, 96: 879-882.

Cabello DR, Lizano E, Valderrama A 1987. Estadísticas vitales de Rhodnius neivai Lent, 1953 (Hemiptera: Reduviidae) en condiciones experimentales. Mem Inst Oswaldo Cruz 82: 511-524.

De la Torre A, Flores LM, Vibanco N 1990. Estudio de transmisores de Trypanosoma cruzi en las zonas rurales de San Blas, Xalisco y Tepic en el estado de Nayarit. Mem II Reun Nal Enf Chagas, Tepic, Nayarit, México, p. 29-31.

Diotaiuti L, Dias JCP 1987. Estudo comparativo do ciclo 
evolutivo do Rhodnius neglectus alimentados em pombos ou camundongos. Rev Soc Bras Med Trop 20: 95-100.

Feliciangeli MD, Rabinovich J 1985. Vital statistics of Triatominae (Hemiptera: Reduviidae) under laboratory conditions. II Triatoma maculata. J Med Entomol 22: 43-48.

Galaviz-Silva L, Jiménez-Guzmán F, Fernández-Salas I, MolinaGarza ZJ, Martínez-Ibarra JA 1991. Datos biológicos de Triatoma gerstaeckeri Stal bajo condiciones de laboratorio. Pub Biol FCB/UANL 5: 81-87.

Galvão C, Jurberg J, Cunha V, Pinto de Mello R 1995. Biologia do Triatoma nítida Usinger, 1939 em laboratório (Hemiptera: Reduviidae). Mem Inst Oswaldo Cruz 90: 657-663.

Gomes AB, Silva IG 2001. Influência da temperatura na biologia de triatomíneos. XXII. Triatoma picturata Usinger, 1939 (Hemiptera: Reduviidae). Entomol Vect 8: 217-228.

Guarneri AA, Diotaiuti L, Gontijo NF, Gontijo AF, Pereira MH 2000b. Comparison of feeding behaviour of Triatoma infestans, Triatoma brasiliensis and Triatoma pseudomaculata in different host by electronic monitoring of the cibarial pump. J Insect Physiol 46: 1121-1127.

Guarneri AA, Pereira MH, Diotaiuti L 2000a. Influence of the blood meal source on the development of Triatoma infestans, Triatoma brasiliensis, Triatoma sordida, and Triatoma pseudomaculata (Heteroptera, Reduviidae). J Med Entomol 37: 373-379.

Guzmán-Bracho C 2001. Epidemiology of Chagas disease in Mexico: an update. Trends Parasitol 17: 372-376.

Juarez E 1970. Comportamento do Triatoma infestans sob várias condições de laboratório. Rev Saúde Públ 4: 147-166.

Lehane MJ 1996. Biology of Blood-Sucking Insects, Harper Collins Academic, London, 427 pp.

Lent H, Wygodzinsky P 1979. Revision of the triatominae (Hemiptera: Reduviidae) and their significance as vectors of Chagas' disease. Bull Am Mus Nat Hist 163: 123-520.

Lewis JH 1996. Comparative Haemostasis in Vertebrates, Plenum Press, New York, 358 pp.

Lima-Gomes JE, Azambuja P, Garcia ES 1990. Comparative studies on the growth and reproductive performances of Rhodnius prolixus reared on different blood sources. Mem Inst Oswaldo Cruz 85: 299-304.

Magallón-Gastélum E, Lozano-Kasten FJ, Flores-Pérez A, Bosseno MF, Breniere SF 2001. Sylvatic triatominae of the Phyllosoma complex (Hemiptera: Reduviidae) around the community of Carrillo Puerto, Nayarit, México. J Med Entomol 38: 638-640.

Magallón-Gastélum E, Magdaleno-Peñaloza NC, KatthainDuchateau G, Trujillo-Contreras F, Lozano-Kasten FJ, Hernández-Gutiérrez R 1998. Distribución de los vectores de la enfermedad de Chagas (Hemiptera: Reduviidae: Triatominae), en el estado de Jalisco, México. Rev Biomed 9: 151-157.

Malo EA, Ramírez-Novelo A, Cruz-López L, Rojas JC 1993. Life cycle and influence of age and feeding on the first mating of Triatoma mazzottii (Hemiptera: Reduviidae). Mem Inst Oswaldo Cruz 88: 203-206.

Martínez-Ibarra JA 2000. Infección con Trypanosoma cruzi y Diferenciación Morfométrica e Isoenzimática de las Poblaciones de Triatominos Vectores de la Enfermedad de Chagas en el Occidente de México, $\mathrm{PhD}$ Thesis, Colegio de Postgraduados, Texcoco, Estado de México, 73 pp.

Martínez-Ibarra JA, Katthain-Duchateau G 1999. Biology of Triatoma pallidipennis (Hemiptera: Reduviidae) under laboratory conditions. Mem Inst Oswaldo Cruz 94: 837-839.

Martínez-Ibarra JA, Bárcenas-Ortega NM, Nogueda-Torres B, Alejandre-Aguilar R, Rodríguez ML, Magallón-Gastélum E, López-Martínez V, Romero-Nápoles J 2001a. Role of two Triatoma (Hemiptera: Reduviidae: Triatominae) species in the transmission of Trypanosoma cruzi (Kinetoplastida: Trypanosomatidae) to man in the west coast of Mexico. Mem Inst Oswaldo Cruz 96: 141-144.

Martínez-Ibarra JA, Miguel-Álvarez A, Arredondo-Jiménez JI, Rodríguez-López MH 2001b. Update on the biology of Triatoma dimidiata Latreille (Hemiptera: Reduviidae) under laboratory conditions. J Am Mosq Cont Assoc 17: 209210.

Novelo-López M, Martínez-Ibarra JA 2002. Biological parameters of Triatoma pallidipennis Stal (Hemiptera: Reduviidae) under laboratory conditions. Mem XXXVII Cong Nal Entomol, Guanajuato, México, p. 472-478.

Paredes-González E, Martínez-Ibarra JA, Nogueda-Torres B 2003. Biology of Triatoma rubida sonoriana (Hemiptera: Reduvidae) under laboratory conditions. Pan-Pacific Entomologist, in press.

Pippin WE 1970. The biology and vector capability of Triatoma sanguisuga texana Usinger and Triatoma gerstaeckeri (Stal) compared with Rhodnius prolixus (Stal) (Hemiptera: Triatominae). J Med Entomol 7: 30-45.

Rabinovich J 1972. Vital statistics of triatominae (Hemiptera: Reduviidae) under laboratory conditions. I Triatoma infestans Klug. J Med Entomol 9: 351-370.

Salazar-Schettino PM, de Haro-Arteaga I, Uribarren-Berrueta T 1988. Chagas disease in México. Parasitol Today 4: 348352.

Sant' Anna MRV, Diotaiuti L, Gontijo AF, Gontijo NF, Pereira MH 2001. Feeding behaviour of morphologically similar Rhodnius species: influence of mechanical characteristics and salivary function. $J$ Insect Physiol 47: 1459-1465.

Schofield CJ 1985. Population dynamics and control of Triatoma infestans. Ann Soc Belge de Méd Trop 65 (Suppl. 1): 149-164.

Southwood TRE 1978. Ecological Methods, 2nd ed., Chapman \& Hall, London, 524 pp.

Velasco-Castrejón O 1991. La Enfermedad de Chagas, Publicación Técnica del INDRE, México, 56 pp.

Velasco-Castrejón O, Salazar-Schettino PM 1996. Enfermedad de Chagas en México. In CJ Schofield, JP Dujardin, J Jurberg (eds), Proceedings of the International Workshop on Population Genetics and Control of Triatominae, INDRE, México, p. 28-29.

Velasco-Castrejón O, Guzmán-Bracho C, Ibáñez-Bernal S 1994. México. In JL Valdespino, O Velasco-Castrejón, A EscobarGutiérrez, A del Río Zolezzi, S Ibánez-Bernal, C MagosLópez (eds), Enfermedades Tropicales en México, Instituto de Diagnóstico y Referencia Epidemiológica, México, p. 279-292.

WHO-World Health Organization 1991. Control of Chagas' Disease, Report of a WHO Expert Committee, 99 pp.

Zárate LG 1983. The biology and behavior of Triatoma barberi (Hemiptera: Reduviidae) in Mexico. III. Completion of the life cycle, adult longevity, and egg production under optimal feeding conditions. J Med Entomol 20: 485-497.

Zárate LG, Zárate RJ 1985. A checklist of the triatominae (Hemiptera: Reduviidae) of Mexico. Intern J Entomol 27: 102127.

Zárate LG, Morales-López G, Cabrera-Ozuna M, GarcíaSantiago G, Zárate RJ 1984. The biology and behavior of Triatoma barberi (Hemiptera: Reduviidae) in Mexico. IV Feeding and defecation patterns. J Med Entomol 21: 548560.

Zeledón R, Alvarado R, Jirón JF 1977. Observations on the feeding and defecation patterns of three triatomine species (Hemiptera: Reduviidae). Acta Trop 34: 65-77 
Zeledón R, Guardia VM, Zúñiga A, Swartzwelder JC 1970a. Biology and ethology of Triatoma dimidiata (Latreille, 1811). I Life cycle, amount of blood ingested, resistance to starvation, and size of adults. J Med Entomol 7: 313-319.
Zeledón R, Guardia VM, Zúñiga A, Swartzwelder JC 1970b. Biology and ethology of Triatoma dimidiata (Latreille, 1811). II Life span of adults and fecundity and fertility of females. J Med Entomol 7: 462-469. 